\title{
HEGEMONY AND AGENCY IN STAGED MAH MERI INDIGENOUS MUSIC AND DANCE PERFORMANCES FOR TOURISTS IN MALAYSIA
}

\author{
Clare Chan Suet Ching \\ Universiti Pendidikan Sultan Idris \\ (clare@fmsp.upsi.edu.my) \\ DOI: https://doi.org/10.22452/jati.vol23no1.7
}

\begin{abstract}
The Mah Meri people are one of eighteen indigenous minority groups in Peninsular Malaysia. The unique Main Jo'oh, their music and dance ritual, is often featured in tourist events, many government-sponsored. While such staged performances support the perpetuation of ethnic identity, the Mah Meri are also subjected to changing levels of hegemony and indigenous agency. I suggest that there is a dynamic interaction between hegemony and agency in Mah Meri staged authentic performances - the hegemony of tourist agents' touristic concepts, the twenty-first century tourist gaze and the emergence of indigenous agency in sustaining the values and customs in their presentations. Through ethnographic fieldwork, interviews and observations, this article shows examples in which Mah Meri mediated cultural performances, perceived as 'authentic' by tourists, were actually shaped by the dialectics of compliance, negotiation and resistance between the Mah Meri, tourist agents and outsiders. This paper promotes a better understanding of the changing meanings of traditional performances recontextualised for stage performances.
\end{abstract}

Keywords: agency, hegemony, indigenous music, Mah Meri, tourism

\section{Introduction}

Power is everywhere, not because it embraces everything, but because it comes from everywhere... Power must be understood... as the multiplicity of force relations immanent in the sphere in which they operate and which constitute their own organisation. (Foucault, 1998, p. 63) 
Foucault's statement on power provides a platform for understanding the interaction between the indigenous Mah Meri, tourist agents, cultural officers and tourists in the reconstruction of Mah Meri staged performances for tourist consumption. Deconstructing the stereotypical binary concepts of power between a perceived stronger and weaker force, Foucault conceives of power as fluctuating between various power structures in an organisation (Foucault, 1980). In this article, I present various ways in which hegemony is disempowered by indigenous agency and vice versa. I use the term 'hegemony' to refer to a perceived dominant power with the capacity to persuade and compel humans to accept and internalise their values and norms. In his concept of 'cultural hegemony', Gramsci (1992) describes a sociopolitical power of intellectual and moral leadership that is able to induce spontaneous consent or consensual agreement from the populace. However, I suggest that while hegemony displays its power, it is not left unchallenged by human agency. Agency has often been left out of in the examination of how performances for tourists have come to be shaped and reshaped. Gidden's (1984) theory on 'structure and agency' discusses the debates between 'structure and agency' as an issue of socialisation. Giddens argues that:

in social theory, the notions of action (agency) and structure presuppose one another; but that recognition of this dependence, which is a dialectical relation, necessitates a reworking both of a series of concepts linked to each of these terms, and of the terms themselves. (Giddens, 2006, p. 53)

'Structure' is defined as the "recurrent pattern of arrangement which limits the choices and opportunities available" (Barker, 2005, p. 448). 'Agency' refers to "the capacity of individuals to act independently and make their own free choices" (ibid). Gidden's description of structure has connectivity with the notion of hegemony theorised by Gramsci and later Foucault. Giddens suggests that we can look at 'structure' as synchronic, a static set of rules, regulations and beliefs or diachronic-dynamic, transformative and regenerative. In this article, I am inclined to lean on a diachronic structure, "the ways in which actors, roles, and rules interact over time, leading to changes in the snapshot (structure)" (Giddens, 2006).

I assert that 'agency' constantly interacts with hegemony in all social structures and organisation. However, these two components occur at different dynamics in differing social organisations. According to Giddens (2006): 
...action or agency...does not refer to a series of discrete acts combined together, but to a continuous flow of conduct. We may define action... as involving a 'stream of actual or contemplated causal interventions of corporeal beings in the ongoing process of events-in-the-world'. (p. 55)

Giddens (2006) asserts that actions do not take place in a vacumm, it interacts with structure and context. He states that, "Actions take place in contexts; and the contexts include crucially the actions of other people and the constraints and opportunities created by social structures" (p. 55). Therefore, the dynamics of hegemony and agency in each organisation is dependent upon the interaction between these two forces.

While examining the intervention of hegemony toward performance structure, I posit that there is also indigenous retaliation and agency in response to hegemony. Through ethnographic fieldwork in Kampung Sungai Bumbun, Carey Island, I present three case studies that exemplify how the Mah Meri music and dance performances perceived as 'authentic', were actually shaped by the dialectics of compliance, negotiation and resistance between the various forces mentioned. I assert and acknowledge that this article was written from the perspective and view of the researcher based on discussions with the Mah Meri musicians and dancers involved. In this article, I argue that musical performances for tourist consumption are constructed through constant negotiation between various power structures, namely Mah Meri people, tourist agents or cultural officers, and the tourists. To contrast staged performances for tourism, I also present two non-staged, real, contemporary weddings held in two different Mah Meri villages.

\section{Background}

The Mah Meri people are one of eighteen indigenous groups known as the Orang Asli (orang: people, asli: original) in Peninsular Malaysia. Their villages are located mainly in the southern coastal plains of the peninsula (Figure 1). Previously hunters, fishermen and crab gatherers, the Mah Meri today are wage earners surviving on income from oil-palm harvesting, woodcarving, weaving and various other odd jobs. Like many indigenous peoples in postcolonial nations, the Mah Meri encounters the hegemonies of nationalistic and touristic discourses. For example, the construction of a bangsa (race/nation) Malaysia, Malaysia's 'imagined community' (Anderson, 1983) envisioned by year 2020, and the 'colorful Malaysia' tourism rhetoric that promotes a 'happy 
multicultural existence' (Sarkissian, 1998) are representations that tend to blur the effects of government policies towards the Mah Meri. These policies include the process of integrating the Mah Meri into the mainstream community through modernisation and conversion into the Malay ethnic category through Islamisation (Nicholas, 2000), gradually diminishing the existence of a people with ancient ancestry in the peninsula. Invitations to be included into the 'Malay' category are long-term goals administered to decrease Mah Meri claims to indigeneity and ancestral territories.

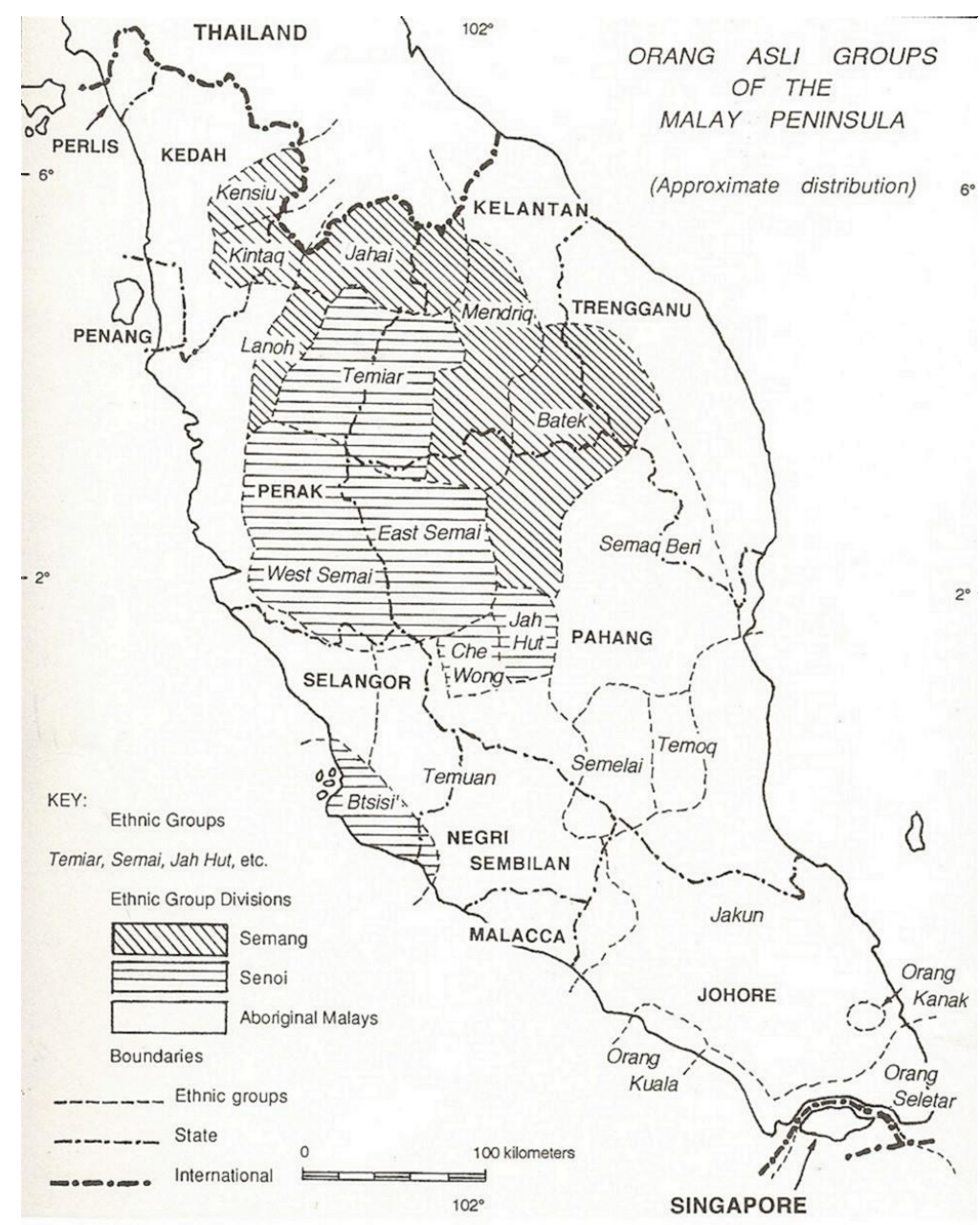

Figure 1: The location of Mah Meri (previously known as Btsisi') settlements among other Orang Asli (original people) in peninsular Malaysia Source: Dentan, Endicott, Gomes and Hooker (1997). 
In Malaysia, a person categorised under the 'Malay' ethnic group is defined as someone who "professes the Muslim religion, habitually speaks the Malay language and conforms to the Malay customs" (Milner, 2011, p. 2). The intention of the government to modernise the Mah Meri toward government notions of a 'progressive' society (Rostow, 1960) often obscures the reality of Mah Meri ancestral lands being exploited for the nation's economic revenue. The conversion of Mah Meri homeland into oil-palm plantations has led to the destruction of the natural ecology of mangrove coastal plains, once abundant with flowing rivers, animals and sea life. Such development schemes have removed the Mah Meri from their previous ecological niche, making it impossible for them to continue their subsistence economy. Instead, Mah Meri people are forced into becoming another 'mechanical reproduction' (Benjamin, 2008) of mainstream society that practices wage labor and who have become entangled in the system of capitalism and consumerism.

Performance is an opportunity for the Mah Meri to express ethnic identity, reclaim the past and recapture the ethos of a once communal village. Mixed sentiments of nostalgia and euphoria support the assertion of ethnic pride for this group of people who have been subjected to different forms of colonialism in the past 500 years, including slavery, exploitation of ancestral lands, religious conversion and assimilation (Andaya \& Andaya, 2001).

\section{The Main Jo'oh}

The traditional music and dance performance of the Mah Meri is the Main Jo'oh, which consists of a group of musicians playing the jule (violin), banjeng (bamboo zither), tungtung (bamboo stampers), tambo (drum), gong and occasionally the ginggong (wooden xylophone) (Chan, 2010) (Figure 2). Female performers dance around a busut (mound) representing the Mah Meri sacred mountain, while male, masked dancers representing the supernatural world try to distract the female dancers by joggling around them and entertaining the audience with their humorous gestures. Representing a divide between the human and supernatural realm, the female dancers pretend to be oblivious to the distractions of the masked dancers (Figure 3). According to the Mah Meri origin myth, two survivors of a great flood, a brother and sister, circled a mountain and met each other again after seven years, seven months and seven days. Finding no other humans, they procreated, producing the Mah Meri descendants of today. The Mah Meri believe that they are the first and original people of the world, while other human beings are their descendants (Karim, 1981). Recreating the past in the present by referencing the primordial, the ancient and myths (Keesing, 1989) of a specific location is one of the ways 
indigenous people assert claims to indigeneity as original inhabitants of Peninsular Malaysia.

Over the past three decades, the Main Jo'oh is often featured in staged Mah Meri weddings and musical dramas, government or privately sponsored performances. In the sphere of tourism, these performances are reconstructed as Mah Meri musicians and dancers, cultural officers, tourist agents and tourists confront each other with different sets of opinions, expectations and desires. This article examines the 'push and pull' or negotiation between compliance and resistance to hegemony and argues that resistance toward hegemony is carried out through creative agency by the Mah Meri. The first case study demonstrates the staging of a Mah Meri wedding with mostly indigenous agency but that is not totally free from some forms of hegemony and Mah Meri resistance to hegemony. The second case study is an example of a staged wedding subjected to the intervention of a tourist agent. Both cases reveal elements of compliance, negotiation and resistance. The third case presents the positive impact of innovation brought into the Main Jo'oh by a cultural officer.

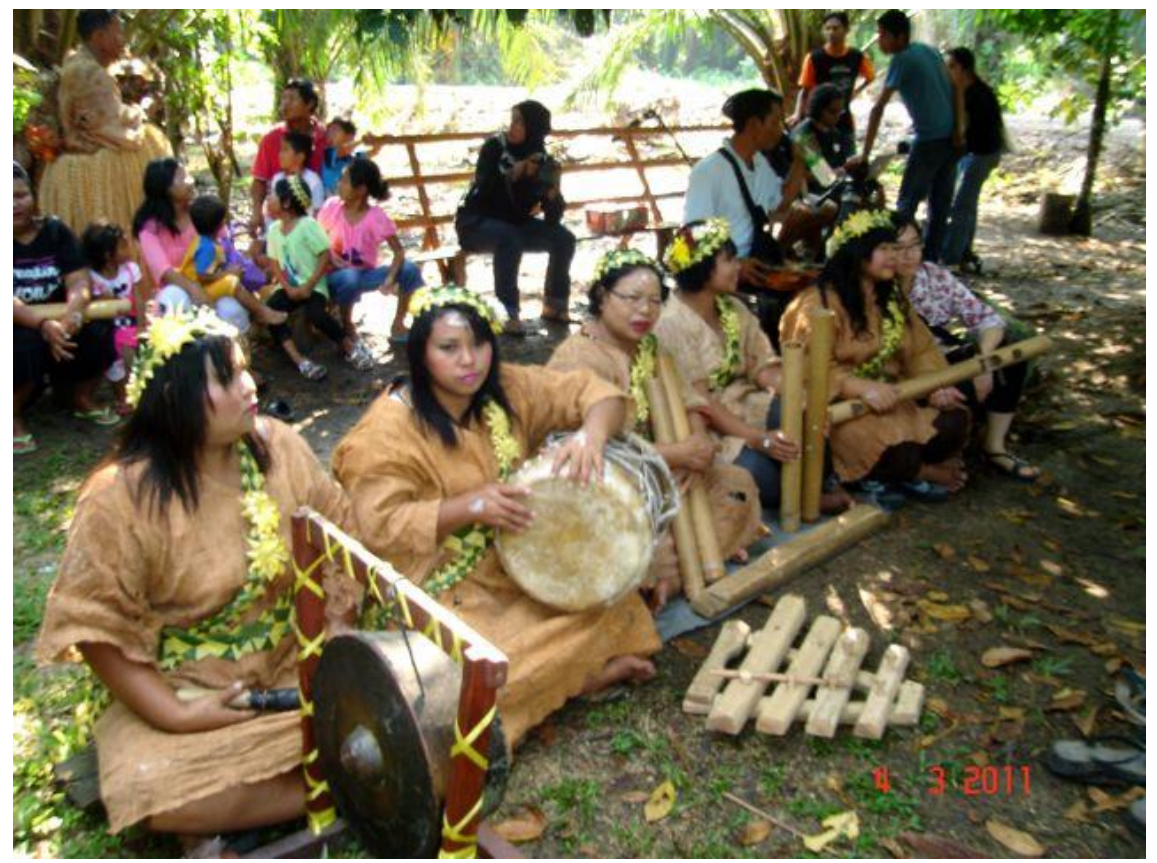

Figure 2: From left: Mah Meri musicians with the gong, tambo (double-headed drum), ginggong (wooden xylophone), two pairs of tungtung (bamboo stamper), banjeng (bamboo-plucked zither)

(Photo by Clare Chan Suet Ching, 2009) 


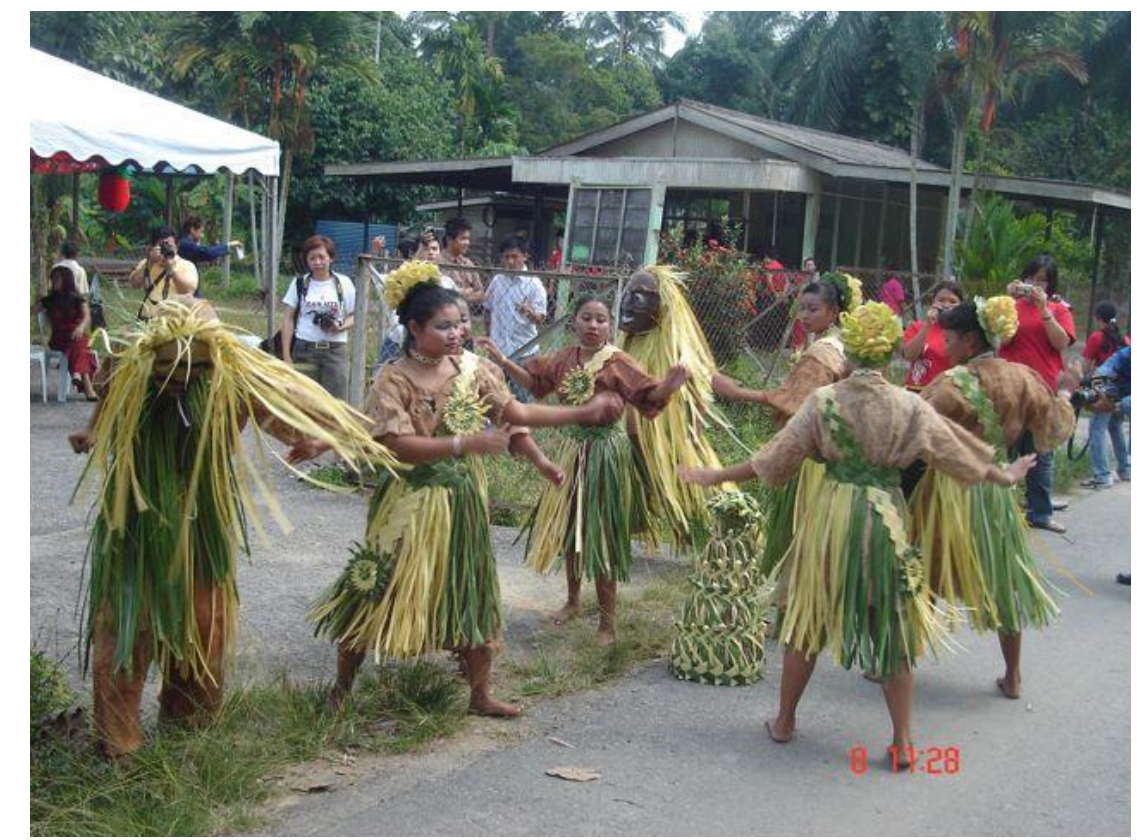

Figure 3: Mah Meri females dancing around a busut (mound), while male masked dancers humour the audience

(Photo by Clare Chan Suet Ching, 2009)

\section{Staged Wedding with Mah Meri Agency}

Showcasing the grandeur of traditional weddings among various ethnic groups is one of many popular tourist events held in Malaysia. On 12 July 2009, the 'Kraftangan Malaysia' (Malaysian Handicraft Centre) invited the Mah Meri of Kampung Sungai Bumbun to present a traditional Mah Meri wedding during the Centre's '1Malaysia Marriage' event sponsored by the Ministry of Communication, Information and Culture (Figure 4). The event was promoted on the 'Tourism Malaysia' calendar. A slogan entitled '1Malaysia Marriage' was splashed across newspapers and the Internet to attract local and international tourists. Capitalising on this buzzword, this event staged traditional marriage ceremonies from seven cultural groupsMalay (Minangkabau), Chinese, Baba Nyonya, Indian, Sabahan (Kadazan), Sarawak (Iban) and Orang Asli (Mah Meri). The Mah Meri were chosen due to their intriguing and elaborate wedding rituals. The promotion of the '1Malaysia' concept of 'unity in diversity' was an previous Najib Razak, previous Prime Minister's (2009-2018) adaptation of the bangsa (one race/ethnicity) Malaysia concept introduced by Mahathir Mohamad the Prime Minister at that time (1982-2003) and now the current Prime Minister (2018- 
present) of Malaysia (Chan, 2012, p. 6) The event was strategised to inculcate nationalistic sentiments among Malaysians. Ironically, these concepts also strengthened and essentialised the identities of ethnic groups.

The Mah Meri participants from Kampung Sungai Bumbun were enthused by the invitation to present a traditional, perceived as 'authentic' wedding. For this staged wedding, the Mah Meri had to recall all the minute details of their traditional wedding ritual. Many of these rituals have been omitted from most Mah Meri weddings today. Collecting information from the memories of their elders, the Mah Meri reconstructed the staged wedding comprised of seven rituals. These rituals are: 1a) merisik (enquiry), 1b) tandak (engagement), 1c) minang (proposal), 2) kateik jemoi (tooth-filing-kateik: cut; jemoi, tooth), 3) berinai (henna staining), 4) perarakan (bride procession), 5) igap kedoh (bride capture-ijap: catch; kedoh: female), 6) bersanding (bridal couple display), and 7) kenduri hum (bathing ritual) (Chan, 2010, p. 328).

During this event, several power struggles were observed between the Mah Meri, the cultural officers and tourists. These struggles involved subverting hegemony and asserting agency. I will elaborate on these struggles through selected examples including the bathing of musical instruments in the smoke from burning kemian (benzoin), the merisik and kenduri hum ritual.

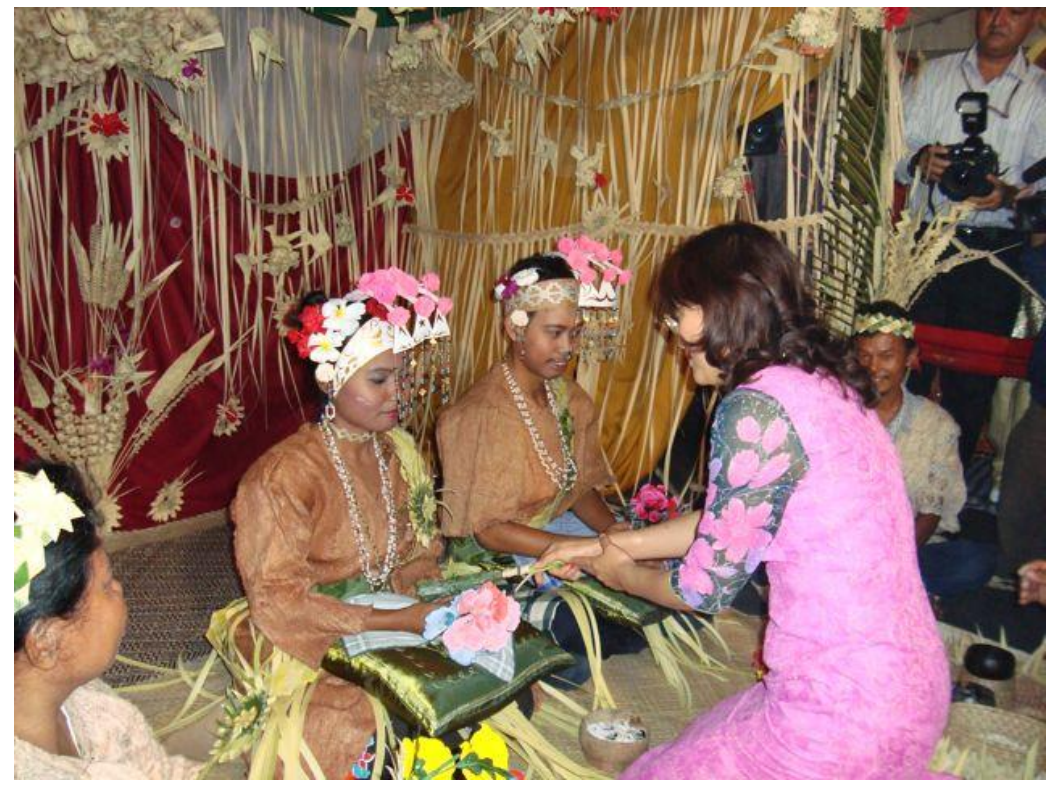

Figure 4: Former Deputy Minister of Information, Communication, and Culture Senator Heng Seai Kie acknowledging the Mah Meri staged bridal couple (Photo by Clare Chan Suet Ching, 2009) 


\section{Subverting Hegemony}

Indigenous agency over performance is observed in the staging of the Mah Meri wedding. Before the staged wedding began, the Mah Meri smoked their musical instruments and bathed their faces and shoulders in kemian (incense). Smoking and bathing in kemian serve to summon their moyang (ancestral spirits) and enable the spirits to see their own faces. While the Mah Meri's animistic beliefs may not be congruent with religious hegemonies of this era, the Mah Meri deem it necessary to perform the protocol of addressing their moyang for permission, protection and blessings for a good performance. Subverting the hegemony of current religious conventions, the Mah Meri perform this initiation ceremony in public.

The Mah Meri began the staged wedding by acting out the merisik (enquiry) ritual. During this ritual, the male's relatives visit a potential brideto-be's family to enquire about her status. Unperturbed by whether the crowd understood their conversations or not, the Mah Meri presented the merisik act in Mah Meri language. The decision not to perform in bahasa Melayu, the national language, one which most Mah Meri are fluent in, shows that there is still pride for their mother tongue-a choice made over conformity to the hegemonic national language.

Kenduri hum (bathing ritual) is an act of cleansing and purification for the bridal couple. The use of specific scented flowers from the old Mah Meri ecology, believed to have purifying qualities along with cleansing lime demonstrate Mah Meri knowledge of indigenous herbs with medicinal value. While many rituals such as 'Hari Gawai Antu' celebrated by the Iban of Sarawak involves the smearing of chicken blood onto the foundation posts of Iban longhouses (Grijih \& Paku, n.d.) and 'Chap Goh Mei', which requires the offering of chicken blood and sacrifice of a black dog (Chan, 2009) during these rituals, such acts will be filtered out especially from the international tourist's view. Similarly, ronggeng, a social dance where women were paid to dance with men at amusement clubs in Malaysia during the early twentieth century, were eliminated from its history when the genre was suggested as representative of the national culture (Tan, 2005). In tourism studies, the 'filtering out' of perceived inappropriate and non-aesthetic scenes is also known as the act of 'sanitising'. Among the seven Mah Meri wedding rituals, kenduri hum would be one of the less appropriate rituals to perform during a staged show. This ritual requires that the newly wedded couple be seated and scrubbed with a layer of fine-pounded rice mixed with water. After the scrub, three huge jars of water would be poured over the couple's heads. Although the ritual itself was a cleansing ritual, it would be generally deemed 
inappropriate for staged shows. Subverting the hegemony of conforming to stage norms, the Mah Meri decided to carry on with this ritual. In true Mah Meri fashion, three huge jars of flower-scented limewater were poured over the couple's heads flooding the stage with much water.

This act showed that the Mah Meri transcended the hegemony of expected norms in staged cultural performances. These tiny acts of resistance resemble Scott's (1985) depiction of the 'weapons of the weak', where subordinate classes throughout history nibble away in sporadic defiance of government policies using 'everyday forms of resistance' such as footdragging, pilfering, false compliance and feigning ignorance. Hobsbawm (1973) describes this as "working the system... to minimise their disadvantage". Unafraid to emphasise difference and uniqueness in their cultural practices, the Mah Meri are able to sustain their cultural identity.

\section{Staging Authenticity}

During weddings in the 1970s, the musicians and female dancers wore sarongs and baju kebaya tops, while the male dancers wore pants and shirts adorned with simple nipa plaited weavings. Music was performed during the second night where villagers gathered to acknowledge the bridal couple during the bersanding (bridal couple display) ritual. The villagers would then break into dancing to Malay joget (a Malay social dance) and Main Jo'oh songs. In today's weddings, a modern pop band would play music from the 1960s, kugiran, rock, dangdut or indigenous pop songs. Dangdut is music that derives from and is a combination of Malay, Hindustani and Arabic music. Kugiran is Malay popular music inspired by American rock and roll during the 1960s. The Orang Asli music bands are not only influenced by Anglo-American music but also transnational and translocal music across the Asian region. The eclectic nature of the Orang Asli facilitates the integration of selected musical aesthetics into their musical productions.

Through interactions with tourists, the Mah Meri discover the needs of tourist audiences. Therefore the Mah Meri stage authenticity by confining the music accompaniment to traditional Main Jo'oh songs and wearing costumes woven from materials gathered from the natural environment. Some of the tourists who look forward to traditional shows are often those who respond to MacCannell's (1976) tourist from modern societies experiencing 'alienation' due to their capitalistic life-style. As MacCannell (1976) notes: "Modern man has been condemned to look elsewhere, everywhere, for this authenticity, to see if he can catch a glimpse of it reflected in the simplicity, poverty, chastity, or purity of others" (p. 41). 
In tailoring to the 'tourist gaze' (Urry, 2002), the Mah Meri perform agency by evoking a self-orientalised modern image of a forest people. Staging authenticity, the Main Jo'oh musicians, female dancers and male masked dancers are costumed in bark cloth tunics decorated with a simpang (sash), songkho (headdress), sanggul (bun), dendan (skirt) and tali pinggan (belt) of woven nipa during the performance of a Mah Meri wedding. The use of indigenous plants and weaving patterns inspired by the flora and fauna endemic to their ecology in their performance costumes is also a way to assert identity and claims to territorial space and visually illustrates their indigenous knowledge of the land.

\section{Inventing traditions}

The non-coded oral tradition of the Mah Meri may result in improvisations and the emergence of several versions of the same ritualistic practice over time. This was observed in the different symbolisms in the kateik jemoi (tooth filing) ritual, raising debate over 'authenticity' (Figure 5). Similar to the Mah Meri marriage ritual, the kateik jemoi is a ritual of initiation into adulthood. The Mah Meri moyang recognise adults that have died by their filed teeth. Batin A said that the tooth-filing ritual is conducted so that the Mah Meri will not 'eat' their children in the future. 'Eat' is a metaphor for the act of incest, a reference to a time when humans were cannibals and committed adultery and incest. Mah Meri origin stories tell of an ancestral spirit known as Moyang Kapir, who stole the 'Book of Conduct' from Moyang Melur. This book consists of rules for human behaviour and conduct. Moyang Kapir distributed the book to humans who quickly began to practice the rules of conduct (Karim, 1981, pp. 80-81).

Julida Uju informed me that she never heard of Batin $A^{\prime}$ s interpretation (personal communication, 12 July 2009). The story they vaguely remember is that tooth filing assures that humans will be able escape the need to bite the seven layers of bamboo after death. They do not know the context behind this belief. The disagreement over the symbolism of the tooth-filing ritual reinforces the observation that oral traditions are dynamic and susceptible to change over time. 


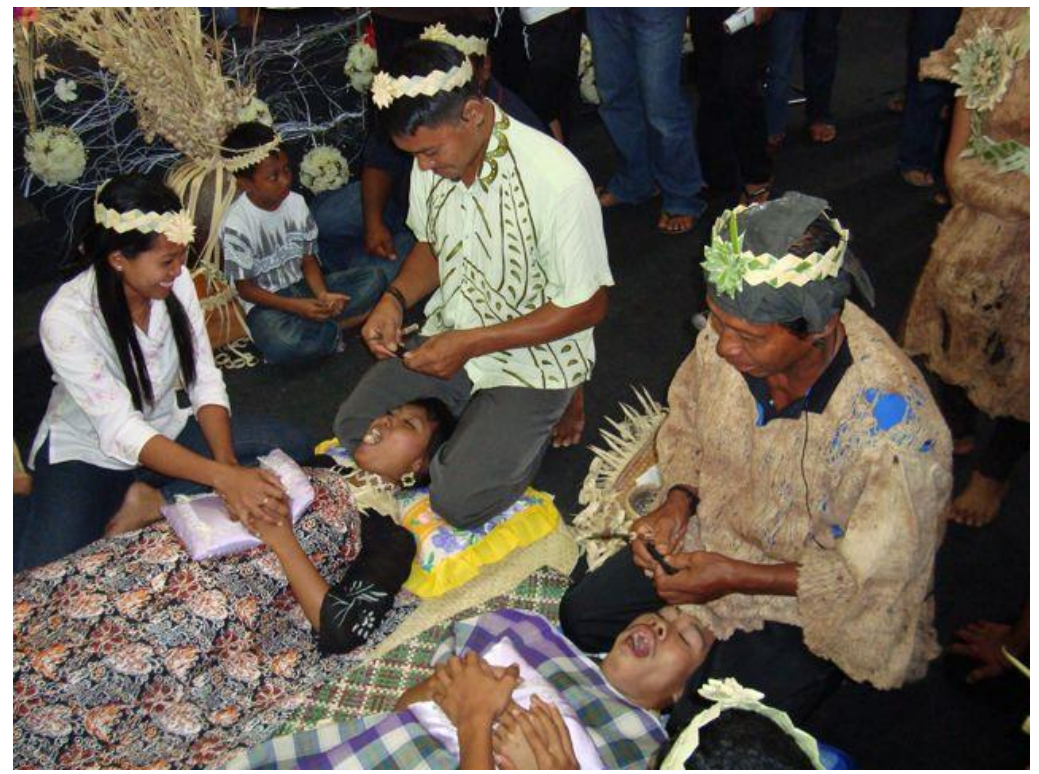

Figure 5: Kateik jemoi (tooth filing)

(Photo by Clare Chan Suet Ching, 2009)

The staged wedding performance thus was an opportunity for the Mah Meri to revive traditional practices and affirm ethnic identity. Whether or not they are being co-opted to promote nationalistic discourses, the Mah Meri use touristic performances as a stage for what Arragon (1995) refers to as stolen opportunities "fleeting chances to circulate knowledge privately and display difference publicly with impunity". While the ability of those who perpetuate dominant culture or hegemonic culture to convince the subordinate to adopt and internalise hegemonic values and norms through spontaneous consent, the Mah Meri perform agency by creatively adapting their music and dance performance as 'weapons' to confront hegemony. While aiming to present an 'authentic' performance, the Mah Meri are actually 'inventing traditions', constructing a new 'authenticity' and creating an 'imagined nostalgia' for traditions that are actually only recent inventions. The longing and nostalgia for a homogenous and communal Mah Meri identity connected to the land and ecology stimulates the invention of this nostalgia.

\section{A Staged Wedding in Kampung Sungai Bumbun Mediated By a Tourist Agent}

The tourist agent often provides the Mah Meri cultural troupe opportunities for income, travel and excitement, and a short-term getaway away from their 
village lives. The tourist agent constitutes a hegemonic force, and although the Mah Meri constantly complain about them, they still continue to comply with the tourist agent's requests for performances. The tourist agent's paradigm, shaped by his interaction with the international and local tourism industry, introduces a different dimension of the tourist gaze. This section analyses a tourist agent's production of a staged wedding in the Mah Meri village of Kampung Sungai Bumbun. In this performance, similar dynamics of subverting hegemony are demonstrated in preparations for the performance.

On 2 April 2009, a private tourist agent mediated a Mah Meri staged wedding for elementary school children from the French School of Kuala Lumpur. The French School consists of children of French, Japanese and Korean expatriates, and who are between ages 7 to 12 . The wedding was staged in Mah Meri village in Kampung Sungai Bumbun, Carey Island, an hour's drive south from Malaysia's capital of Kuala Lumpur toward the coastal plains of the west coast. During the staged wedding, Mah Meri Musician A, the cultural troupe's violinist was asked to play the Mah Meri wedding song, a song played by his late father years ago. This song may be the henna-staining song mentioned by Nowak (1987) in the 1980s:

Picking up the rhythm of the laguk yinai (henna-staining song), the musicians are playing, the shamans begins dancing. The dance, though improvised, resembles Malay silat (Malay martial arts) style. With the candles in his hands, the shaman dances, his hands moving under and above each other, like juggler. (p. 101)

Mah Meri Musician A played the wedding song to accompany male guests who took turns to acknowledge the bridal couple by juggling two bowls of rice in stylised movements resembling silat (Malay martial arts). Mah Meri Musician A said he vaguely remembered the song but that he would play it anyway. However, from my knowledge of Mah Meri musical repertoire, I realised that Mah Meri Musician A was actually playing the Si Ooi Song (Song of Peacock Pheasant) instead of the 'vaguely remembered wedding song'. I suggest that this action implies two things: firstly, the tourist agent who is an outsider, had instructed Mah Meri Musician A to play the Mah Meri wedding song. Mah Meri Musician A subverted hegemony by taking advantage of the tourist agent's lack of knowledge in the Mah Meri musical repertoire to improvise music for the staged wedding. Secondly, traditional Mah Meri music and musicians are good improvisers and flexible performers such that 
although certain songs were indeed associated with certain rituals, there are no fixed ways to perform the music. Unlike many standardised cultural shows choreographed for tourist consumption, this non-codified nature of folk traditions and the Mah Meri's characteristic of adaptability allowed room for spontaneous creativity.

The children from the French School of Kuala Lumpur came to experience an alternative life-style that is different from the city. Upon the children's arrival, the Mah Meri performed instrumental Main Jo'oh music to welcome them. The children then surrounded the plamin (bridal stage) set up on a woodcarving shed, snapping photos with their digital cameras. The tourist agent explained the seven complicated rituals in Mah Meri weddings, but he said he would only highlight some. The first ritual was a traditional hand-held puzzle with which the groom had to solve, testing his intelligence before he could marry the girl. This game of wooden blocks and strings, known as the tali jodoh or buai tetap, is a traditional Mah Meri game sold commercially today. The object of the puzzle is to bring together the separated pieces (representing husband and wife) on the same string to gauge the probability of one finding a life partner. When questioned about which part of the ritual this belonged to, Mah Meri Dancer A told me, "tak adalah, tu dia yang cipta punya" (No, he came up with this idea himself). Although this game relates to marriage, it is not one of the marriage rituals. The tourist agent merely incorporated it as one of the marriage rituals to entertain client visitors.

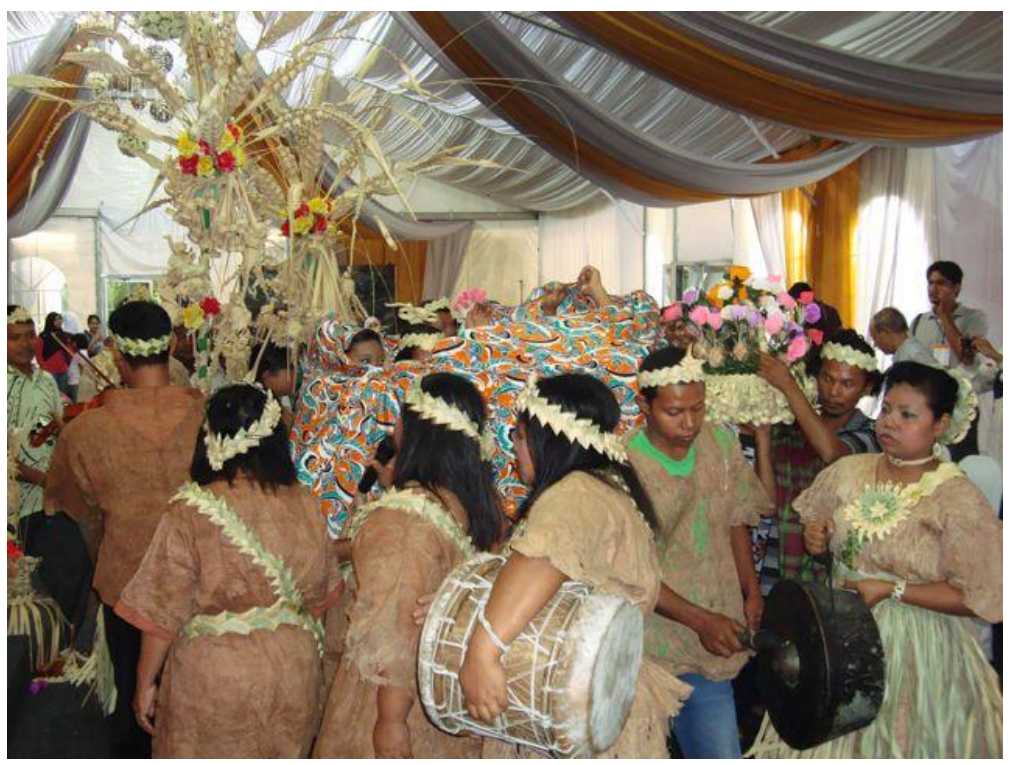

Figure 6: Igap Kedoh (bride capture)

(Photo by Clare Chan Suet Ching, 2009) 
The staged wedding revives many practices symbolic of the Mah Meri cosmology. An example is the igap kedoh, the bride-capture ritual that is conducted before the groom is able to meet his bride (Fig.6). A series of playful silat matches (Malay martial arts) occur between the representatives of the male and female. Once the groom's entourage breaks through the barrier, he is faced with his future bride's kinswomen, who try to hide the bride by encircling her and wrapping a large cloth around them. The bride is placed at the center representing the busut (mound) a symbol of the Mah Meri's origin myth. The groom will have to choose the right stretched-out hand of his bride among the ladies in the circle. The tourist agent explained the igap kedoh (bride capture) ritual, saying that if the groom changed his mind about marrying the bride, he could purposely choose another girl in the bridal capture circle at the last minute. Also, if he chose the wrong bride, it was fated that they were not meant to marry. This statement added some element of drama and excitement to the ritual. However, when I translated his explanations, Mah Meri Dancer A merely laughed and said the bride's kinswomen inside the circle usually help direct the groom's hand to the bride's hand so that they find each other in the circle. Since the tourist agent spoke in English, the Mah Meri were oblivious to dramatised narration he delivered in order to entertain the audience. The little control the Mah Meri had over the tourist agent's intervention is an example of an inevitable submission to hegemony.

For the wedding finale, Mah Meri Musician B carried a miniature carving of a pahuk (boat) and led the French children into a 'Culture Garden' fenced with leaves from the nipa plant located behind the bridal stage, for an additional view of Mah Meri culture. The tourist agent had instructed the Mah Meri to build this garden for this particular visit. In the Culture Garden, the Mah Meri were instructed to display woodcarvings of Mah Meri traditional items such as masks, boats, baskets, blowpipes and other artifacts. This pahuk was formerly used in healing ceremonies and had no connection with Mah Meri weddings. During healing ceremonies, woodcarvings of figurines used as gift exchanges for the souls of the sick were placed on the boat and launched out to sea.

When the children entered the 'Culture Garden' to view the items, the space separating the Mah Meri performers and children was broken. The children began asking the masked dancers many questions, such as, "What is in your huge belly?" The masked dancers are representatives of the moyang (ancestral spirits) of the Mah Meri. Humans and spirits are separate entities that do not meet. Dissatisfied with the mumbling sound he made under his mask, they started hitting his stomach. As he ran, they chased him. The aura of 
mystery behind the masked dancer descended into a game of 'catch me if you can' game. This impingement of space between the masked performer and audience disrupted the Mah Meri belief system that perpetuates the division between the human and spiritual world.

Based on his experience in the international tourist scene, the tourist agent tried to create a more spectacular but compact version of the Mah Meri wedding. He extracted interesting aspects of the culture and combined them to create his own cultural representation. In the tourism world, many representations of authentic performances such as the kecak (Monkey Dance) or barong of Bali, Gorale tourism in Poland (Cooley, 2005) and Maasai performances in Nairobi (Bruner, 2005) are products of tourist agents, ethnographers and the people themselves. Kreasi baru (new creations) occurs in kakula performances of the Kaili society of Central Sulawesi as a result of various hegemonic discourses (Santaella, 2014, pp. 66-83). Indeed, indigenous peoples do not live in a vacuum today. Instead, they constantly interact with various powers because of their involvement in tourist activities. Although the Mah Meri appear to succumb to the hegemony of the tourism industry, I argue that Mah Meri people are not totally disempowered in these situations. They are exposed to various ways of responding to the nature of the tourist industry. In future, they may recreate or sustain the authenticity of their cultural traditions to cater to tourist consumption.

\section{Innovations to the Main Jo'oh by a Cultural Officer}

On 12 July 2009, the Mah Meri were invited to perform for the interim entertainment sections, as representatives of grassroots troupes during the Festival Tari Malaysia (Malaysian Dance Festival) competition. A government cultural officer was assigned to facilitate the Mah Meri performance during this event. He developed a warm relationship with the Mah Meri musicians and dancers, teaching them stage make-up skills and spicing up their looks. In this show, he even dotted an improvised 'Marilyn Monroe mole' above the women's lips. An audience member commented, "The female dancers can't be Orang Asli, they are too beautiful." This is a typical comment constantly made about the indigenous people even until today. The audience expected the Mah Meri to look unrefined and coarse. Some of the Mah Meri dancers, young and old, shaped their eyebrows and straightened their hair-they did not like their curly black hair. Somehow, the Mah Meri's involvement in tourism events also introduced them to a globalised aesthetic of beauty (Figure 8). The aesthetics of beauty for Mah Meri people, once appreciated by tourists for its rougher, coarse and darker skin and their own make-up styling, had been replaced with 
a foreign make-up style. Although the make-up made the Mah Meri look 'more beautiful' in a modern sense, it also reflected the growing homogenisation of the aesthetics of beauty spread across the globe by mega cosmetic conglomerates such as Estee Lauder, Revlon and Elizabeth Arden. The notions of what it means to be beautiful today have been globalised through images of supermodels and famous actresses disseminated through the media. In the photos from Ari Moyang (Ancestral Day) on 16 March 2010 and 5 March 2011, I observed that the Mah Meri used the 'Marilyn Monroe mole' and the stage make-up they had learned from the Malaysian government officer (Figure 7). This example shows the influence of new ideas from beyond their ancestral homeland into the portrayal of their public image.

The cultural officer added false eyelashes, heavy stage make up and some chrysanthemum flowers to the girls' headdresses. Enthusiastic about the Main Jo'oh, the male cultural officer asked to play one of the masked characters-the female Moyang Puteri Gunung Ledang (Princess of Ledang Hill Spirit). With their permission, the cultural officer added lipstick and false red glittery eyelashes to the female mask. He also plucked fresh red hibiscus flowers and placed these upon mask's ears. Although the Mah Meri enjoyed his company, Mah Meri Dancer A reminded him not to be too asyik (obsessed) while dancing, for the spirit he played might possess him.

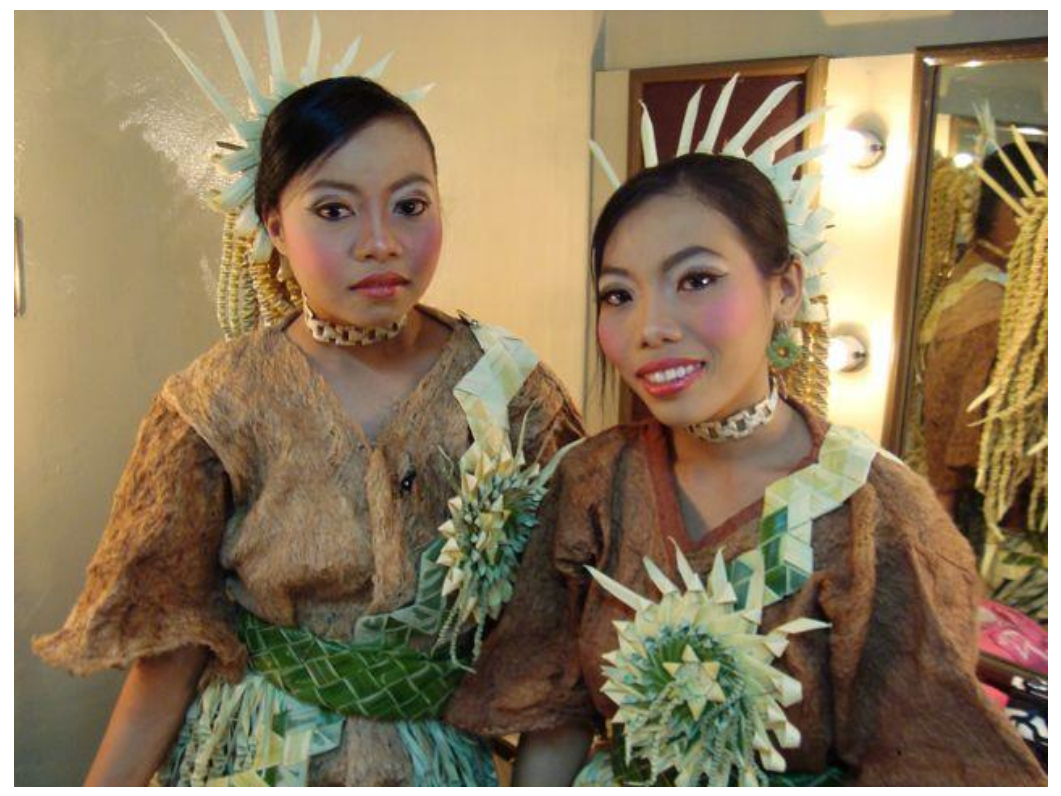

Figure 7: Mah Meri dancers with professional make-up

(Photo by Clare Chan Suet Ching, 2009) 
This cultural officer's vain impersonation of the female ancestral spirit triggered roars of laughter and applause from the local audience. He blew kisses, slightly lifted his skirt, sat cross-legged at the edge of stage and flirted with the other masked dancers. He responded to the revolving video camera by posing bashfully in front of the camera. The two male masked dancers wearing Moyang Pongkol (Pongkol Spirit) and Moyang Tok Naning (Tok Naning Spirit) masks were motivated to interact with the playful actions of this outsider. The Mah Meri did not see this as a bastardisation of their culture, but as a positive innovation to the Main Jo' oh as the masked dancer's role has always been to entertain the audience. Rosiah Kengkeng says, "In the old days, the masked dancers were very good making the villagers laugh with their mischievous and naughty actions" (personal communication, 7 March 2009). The masked dancer responds differently to the audience and environment. The outsider's performance provided the Mah Meri masked dancers with new and creative ways to perform their roles.

Tourism performances provide a place for Mah Meri ethnicity in a changing world. These performances for tourists are what Appadurai (1996) calls, "cultural performances that express the mobilisation of group identities". This event affirms Cohen's notion of 'tourism as play' and Rosaldo's observation as "sites of creative cultural production" (Rosaldo, 1989). Although some observers might see these interventions as disempowerment of or condescension for the Mah Meri, I argue that in this century, it is inevitable that Mah Meri people have to negotiate encounters with various forces. They can choose to subvert, merge or adapt their performances, and their choices merit future research. The dynamics of change and continuity persist each time the Mah Meri perform in various venues, respond to different audiences and interact with an increasingly wider, globalised audience.

\section{Non-Staged Contemporary Mah Meri Weddings}

Two different non-staged wedding rituals in two different villages of Carey Island provide and reflect greater Mah Meri agency. The following two sections describe the choices for choreographing weddings available to young Mah Meri couples. The choices depend on the importance that each family places on adat (custom) and the sanctity of the marriage act in a period during which moral values are vulnerable to contemporary local and global influences. 


\section{Traditional Wedding at Kampung Sungai Bumbun}

A second non-staged wedding reflects another reconstruction of traditional practice initiated by the Mah Meri people themselves. Through the merisik (enquiry) ritual, the groom from Kampung Sungai Bumbun was introduced to his bride from a Mah Meri village in Kampung Pulau Lumut, Selangor. After a few meetings, the couple agreed to wed. The couple chose a more traditional wedding. Unlike the elaborate tajuk (headdress) worn for the staged wedding described earlier, flowers woven from nipa were placed on the bride's head. Instead of the tunic of bark cloth worn for tourist performances, the bride wore a pink baju kebaya (traditional Malay female attire) and white transparent selendang (shawl) embellished with a simple simpang (sash), bunga jering (jering flower), tali pinggang (belt) and dendan (skirt). The groom wore a baju melayu (traditional Malay male shirt), pants, sarong and a songkho (headgear) made from nipa leaves.

The traditional music ensemble played Main Jo'oh songs as background music for the wedding. Of the seven wedding rituals, the couple retained six: the merisik (enquiry), minang (proposal), bersanding (bridal display), kateik jemoi (tooth filing), kenduri hum (bathing ritual), and nyampak rituals. The musicians played the Jaboi song to accompany the couple's procession to the bridal stage for the bersanding (bridal display) ritual. Batin A conducted the marriage rituals with the ukup ritual of bathing his hands in kemian (incense) and pressing it onto the couple's heads, chins, shoulders and legs. He also performed some silat (Malay martial arts) movements with bowls of rice with three candles in each bowl. The other male visitors often acknowledge the newlywed couple with the same act.

Villagers and guests also acknowledged the couple as the male guests entertained the villagers with personalized silat movements. While the igap kedoh ritual (bride capture) was omitted, the nyampak was kept, a ritual considered essential to a couple's marriage education. An elderly woman spoke about proper marriage behaviour while the couple fed each other rice and areca nut wrapped in betel leaf, symbolising that they must now learn to share equally with each other. During the bersanding ceremony, the couple was led to the garden where they were each provided with a sarong for the kenduri hum ritual. Three jars of water were splashed over the couple as an act of purification.

After this ritual, the villagers enjoyed lunch to background Malay music from a CD player, while the Main Jo'oh ensemble rested. The opoh (extended family) had come together to cook food for several villages in big cauldrons. Later, the children and teenagers adjourned to Gendoi Samah 
Seman's house where a karaoke machine played Malay songs such as 'Penawar Rindu'. The Mah Meri traditional wedding today encompasses a combination of cultural contact and modernisation. The Mah Meri's innate and inherited nature of spontaneity, mobility and flexibility allow enrichment toward a certain kind of 'freshness' in their musical productions.

\section{Modern Wedding at Kampung Sungai Rambai}

On 14 March 2009, a young Mah Meri couple married in Kampung Sungai Rambai, Carey Island. The bride who was dressed in a resplendent Western wedding gown, and the bridegroom who wore a suit, sat on chairs on the plamin (bridal stage) instead of traditionally sitting on the floor. They cut the wedding cake and fed it to their in-laws with a spoon. The cake cutting is a recent addition borrowed from Western weddings.

Mah Meri Musician C, an elderly jule player from a Mah Meri village, Kampung Tanjong Sepat, Selangor on the west coast of the peninsula, was invited. His relatives are also musicians in Kampung Sungai Judah, Carey Island. These musicians met at Kampung Sungai Rambai for the couple's wedding, during which they performed the Ganding Song. The Kampung Sungai Judah version of the Ganding Song that accompanied the cake-cutting ceremony, was slightly different from that of Kampung Sungai Bumbun. 'Destinasi', a Temuan (Orang Asli subgroup) modern band, accompanied the Gendol on his jule until he got tired and stopped. The bass guitar softly plucked chords while the drummer provided rhythmic accompaniment.

The band played a Spanish language song called 'Besame Mucho' while the perarakan (bridal procession) entered the house. Soon all generations scurried into the dance area as the band began playing Malay songs from the 1960s, kugiran and dangdut, and Orang Asli pop songs such as 'Joget Baju Kurung' (Baju Kurung joget), 'Joget Kapal Terbang' (Airplane joget) and 'Panas-panas.' Vendors sold food and drinks outside the balai. Young male teenagers arrived on motorbikes. A few elderly Mah Meri men who were inebriated, danced clumsily on the floor while young children and teenagers danced the joget together with their gomok (aunts) and friends. Females tended to dance with females and males with males, a practice documented by Nowak in the 1980s.

This couple had chosen a more modern style of wedding. They were able to select the style of dress, conducted new and old rituals and performed some traditional and many popular Malay and Orang Asli music pieces. 


\section{Conclusion}

The performance of the staged wedding is an opportunity for the: 1) assertion and affirmation of indigenous identity; 2) to respond to hegemony; and 3) invention of tradition. The wedding also becomes a space for the villagers to work together and rejuvenate their traditional customs. In learning the significance of each ritual, traditional Mah Meri values and wisdom are transmitted to the younger Mah Meri. In 'staging authenticity' the Mah Meri respond to their nostalgia for the past while playing to the tourist gaze. These performances affirm Cohen's notion of 'tourism as play' (Cohen, 2004) and Rosaldo's observation (1989) as 'sites of creative cultural production'.

The different types of staged wedding show variation suggests Mah Meri agency. The first staged wedding reveals the primacy of Mah Meri agency with little intervention from outsiders. This case shows that there is space for the assertion of Mah Meri values, tradition and agency, especially illuminating for government organisations interested in authentic performances. The stories of Moyang Melur and Moyang Kapir from the Mah Meri meta-narratives are adapted and given a fresh interpretation in Mah Meri performances. This wedding integrated memories of the traditional as the Mah Meri reinvented rituals in contemporary ways. Integrated memories are also platforms for cultural rejuvenation that optimise Mah Meri creativity, thrusting their aesthetics into the limelight. However, these reinventions are also restrained by the village's musical troupe goals of cultural preservation and assertion of ethnic identity. Keesing (1989) notes that the

ancestral ways of life being evoked rhetorically [or in the Main Jo'oh case, through performance] may bear little relationship to those documented historically or recorded ethnographically, and reconstructed archaeologically-yet their symbolic power and political force are undeniable.

I support Keesing's suggestion that it does not matter whether the past being recreated or invoked is accurately represented. Rather, the recreation of meta-narratives to facilitate the retention of identity, ethnic empowerment and ancestral territories is what matters more.

The second staged wedding and national dance festival manifest forms of neocolonialism. The third example welcomed the participation of an outsider. Viewed in a positive light and through the lens of an outsider exposed to the tourism industry, outsider influences inform Mah Meri people on possible ways to recreate their performances. Whether or not Mah Meri 
performers continue to reproduce the ideas mediated by the cultural officers are worth future research. This article shows that there are various levels of authenticity represented by different agencies and power structures. Based on their habitus (Bourdieu, 1990), different tourists witnessing different staged weddings come away with what they consider to be an authentic version of Mah Meri weddings. What is signified onstage for audiences vary according to the power relations inherent in the preparations for different events. While staged performances reveal negotiations between hegemony and agency, nonstaged weddings show agency among modern Mah Meri couples in adapting their wedding to include traditional or modern, or a combination of both elements.

This article creates awareness that cultural performances today are created and recreated when different power structures confront each other with different motives and agendas. The cultural products that emerge from staged entertainment and that are derived from indigenous cultural traditions for visitors and tourists are products of negotiation, resistance and adaption. This process also shows that worldviews and religions constantly adapt and acquire new meanings in an ever-changing socio-political situation. Although gradual absorption into modernity is inevitable, Mah Meri people use whatever resources they can to maintain the ethos and values of their community. Performances for tourists are constructed out of power struggles between the Mah Meri and hegemony whereby the outcome is the space where the 'tug of war' is at equilibrium. This paper reveals the dialectics of their resistance in response to hegemony-a push forward and a pull backward.

\section{References}

Andaya, B. W., \& Andaya, L. Y. (2001). A history of Malaysia (2 ${ }^{\text {nd }}$ ed.). Honolulu: University of Hawai'i Press.

Anderson, B. (1983). Imagined communities: Reflections on the origin and spread of nationalism. London: Verso.

Appadurai, A. (1996). Modernity at large: Cultural dimensions of globalization. Minneapolis: University of Minnesota Press.

Arragon, L. V. (1995) Suppressed and revised performances: Raego' songs of Central Sulawesi Indonesia, Ethnomusicology, 40(3), 413-439.

Barker, C. (2005). Cultural Studies: Theory and practice. London: SAGE Publications. 
Benjamin, W. (2008). The work of art in the age of mechanical reproduction. (J. A. Underwood, Trans.). London: Penguin.

Bourdieu, P. (1990). The logic of practice, (R. Nice, Trans.). Stanford, CA: Stanford University Press.

Bruner, E. M. (2005). Culture on tour: Ethnographies of travel. Chicago: University of Chicago Press.

Chan, C. S. C. (2010). Mah Meri onstage: Negotiating national policies, tourism, and modernization in Kampung Sungai Bumbun, Carey Island, Malaysia. Ph.D. dissertation, Graduate Division, University of Hawai'i at Manoa, United States.

Chan, C. S. C (2012). Heterogeneity in the musical acquisition of Orang Asli children from the Mah Meri and Semai groups. Malaysian Music Journal, 2(1), 1-19.

Chan, M. (2009). Chinese New Year in West Kalimantan: Ritual theatre and political circus. Chinese Southern Diaspora Studies, 3, 106-142.

Cohen, E. (2004). Contemporary tourism: Diversity and change. Amsterdam: Elsevier.

Cooley, T. J. (2005). Making music in the Polish Tatras: Tourists, ethnographers, and mountain musicians. Bloomington: Indiana University Press.

Dentan, R. K., Endicott, K., Gomes, A. G., \& Hooker, M. B. (1997). Malaysia and the "original people": A case study of the impact of development on indigenous peoples. Boston: Allyn and Bacon.

Foucault, M. (1980). Power/Knowledge: Selected interviews and other writings, 1972-1977. (C. Gordon, Trans.). New York, NY: Pantheon Books.

Foucault, M. (1998). The history of sexuality: The will to knowledge. London: Penguin.

Gramsci, A. (1992). Prison notebooks (European perspectives). New York, NY: Columbia University Press.

Giddens, A. (2006). Central problems in social theory: Action, structure and contradiction in social analysis. Berkeley: University of California Press.

Grijih, H., \& Paku, S. (n.d.). Gawai Antu, Iban feasts of the departed. Retrieved from https://tusunterabai.wordpress.com/adat-main-asal-lekamain/gawai-antu/

Hobsbawm, E. (1973). Peasants and Politics. Journal of Peasant Studies 1(1), 3-22.

Karim, W. J. B. (1981). Ma' Betisék concepts of living things. London: Humanities Press.

Keesing, R. M. (1989). Creating the past: Custom and identity in contemporary Pacific. The Contemporary Pacific, 1(12), 19-42.

MacCannell, D. (1976). The tourist: A new theory of the leisure class. New York, 
NY: Schocken Books.

Milner, A. (2011). The Malays. West Sussex: Blackwell Publishing Ltd.

Nicholas, C. (2000). The Orang Asli and the contest for resources: Indigenous politics, development and identity in Peninsular Malaysia. Copenhagen: IWGIA.

Nowak, B. S. (1987). Marriage and household: Btsisi' response to a changing world. Ph.D. dissertation, Department of Anthropology, State University of New York at Buffalo, United States.

Rosaldo, R. (1989). Culture $\mathcal{E}$ truth: The remaking of social analysis. Boston: Beacon Press.

Rostow, W. W. (1960). The stages of economic growth: A non-communist manifesto. Cambridge: Cambridge University Press.

Santaella, M. A. (2014). Tradition, Kreasi Baru and Ethnotainment: Three representational kakula spheres among the Kaili of Central Sulawesi. Malaysian Music Journal, 3(2), 66-83.

Sarkissian, M. (1998). Tradition, tourism, and the cultural show: Malaysia's diversity on display. Journal of Musicological Research, 17(2), 87-113.

Scott, J. C. (1985). Weapons of the weak: Everyday forms of peasant resistance. New Haven: Yale University Press.

Tan, S. B. (2005). From folk to national popular music: Recreating ronggeng in Malaysia. Journal of Musicological Research, 24, 287-308.

Urry, J. (2002). The tourist gaze. London: SAGE Publications.

Date Received: 15 November 2017 Date of acceptance: 15 April 2018 